\title{
Factors determining exercise capacity in patients with atrial septal defect: assessment of heart function with CMR during dobutamine stress
}

\author{
Sigurdur S Stephensen ${ }^{1,2^{*}}$, Katarina Steding-Ehrenborg ${ }^{2}$, Ulf Thilén ${ }^{3}$, Johan Holm³ Peter Hochbergs $^{4}$,
} Håkan Arheden ${ }^{2,4}$, Marcus Carlsson 2,4

From 18th Annual SCMR Scientific Sessions

Nice, France. 4-7 February 2015

\section{Background}

Patients with left to right shunting of blood through an atrial septal defect (ASD) have decreased exercise capacity. This study hypothesized that central factors influence exercise capacity, namely systemic and pulmonary cardiac output and right ventricular (RV) function during stress as well as left atrial pressure (LAP) and pulmonary artery pressure (PAP). Previous studies have found varying effects of stress and increased heart rate on the degree of shunting. The purpose of the study was therefore to determine if atrial shunting ratio changes during stress and examine if central factors can explain decreased exercise capacity in ASD patients.

\section{Methods}

Eighteen patients with ASD and 16 healthy volunteers underwent cardiac magnetic resonance at rest and during $20 \mu \mathrm{g} / \mathrm{kg} / \mathrm{min}$ dobutamine infusion and 0.25-0.75 $\mathrm{mg}$ atropine injection, aiming for an increase in heart rate to at least $70 \%$ of age-predicted maximal pulse. Two patients could not undergo stress CMR. Cine ssfp images were used for LV and RV volumes. Flow velocity mapping of the aorta and pulmonary trunk quantified cardiac output and shunt ratio (QP/QS) at rest and during stress. Ergospirometry was used to determine peak oxygen uptake $\left(\mathrm{VO}_{2}\right.$ peak). LAP and PAP were invasively measured at rest at the time of transcutaneous closure of the ASD.

\section{Results}

Subject characteristics are shown in table 1 . In patients with ASD the shunt ratio decreased from $2.2 \pm 0.8$ at rest to $1.6 \pm 0.6(\mathrm{p}<0.01)$ during dobutamine stress. On dobutamine stress systemic cardiac output increased by 81 $\pm 37 \%$ and pulmonary cardiac output increased by 30 $\pm 28 \%$ ( $\mathrm{p}<0.001)$. $\mathrm{VO}_{2}$ peak correlated with cardiac output

Table 1 Subject characteristics

\begin{tabular}{|c|c|c|c|c|}
\hline & \multicolumn{2}{|c|}{ ASD patients } & \multicolumn{2}{|c|}{ Healthy controls } \\
\hline N & \multicolumn{2}{|r|}{18} & \multicolumn{2}{|r|}{16} \\
\hline Mean age and range & \multicolumn{2}{|c|}{$51 \pm 18$} & \multicolumn{2}{|c|}{$35 \pm 13$} \\
\hline Females, n (\%) & \multicolumn{2}{|c|}{$13(72)$} & \multicolumn{2}{|c|}{$3(19)$} \\
\hline $\mathrm{BSA}, \mathrm{m} 2$ & \multicolumn{2}{|c|}{$1.9 \pm 0.2$} & \multicolumn{2}{|c|}{$1.9 \pm 0.2$} \\
\hline \multirow[t]{2}{*}{ Peak oxygen uptake on ergospirometry (ml/min) } & \multicolumn{2}{|c|}{$1795 \pm 661$} & \multicolumn{2}{|c|}{$3482 \pm 624$} \\
\hline & Rest & Dobutamine stress & Rest & Dobutamine stress \\
\hline Heart rate, bpm & $73 \pm 11$ & $124 \pm 11$ & $65 \pm 19$ & $134 \pm 12$ \\
\hline Cardiac output (L/min) & $4.8 \pm 0.9$ & $8.8 \pm 2.8$ & $7.0 \pm 1.5$ & $11.8 \pm 2.1$ \\
\hline Shunt, QP/QS & $2.2 \pm 0.8$ & $1.6 \pm 0.6$ & $1.0 \pm 0.1$ & $1.0 \pm 0.1$ \\
\hline
\end{tabular}

'Department of Pediatric Cardiology, Lund University Hospital, Lund, Sweden

Full list of author information is available at the end of the article 

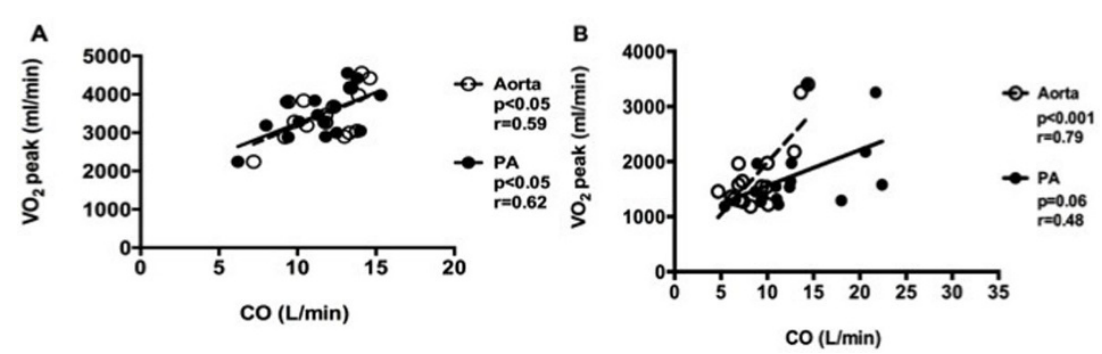

Figure 1 Linear regression analysis between systemic (Aorta, dotted line) and pulmonary (PA, solid line) cardiac output during dobutamine stress and $\mathrm{VO}_{2}$ peak in healthy controls (A) and patients with ASD (B).

at dobutamine stress in controls (fig 1A), but only with aortic cardiac output in patients with ASD (fig 1B). $\mathrm{VO}_{2}$ peak did not correlate with $\mathrm{QP} / \mathrm{QS}$ in patients $(\mathrm{p}=0.22$ at rest and $\mathrm{p}=0.29$ at stress). $\mathrm{VO}_{2}$ peak correlated with $\mathrm{RV}$ end systolic volume during stress in controls $(\mathrm{p}<0.01)$ but not in patients $(\mathrm{p}=0.56)$. There was no correlation between $\mathrm{VO}_{2}$ peak and LAP or PAP at rest $(\mathrm{p}=0.45$ and $\mathrm{p}=0.71$ respectively).

\section{Conclusions}

The shunting ratio in ASD patients decreases during dobutamine stress. This is explained by proportionally larger increase in systemic flow compared to shunting flow. Exercise capacity in patients is related to the capacity to maintain a high systemic cardiac output during stress but not to the degree of shunting, RV function at stress or to LAP or PAP at rest.

\section{Funding}

The Swedish Heart-Lung Foundation.

\section{Authors' details}

${ }^{1}$ Department of Pediatric Cardiology, Lund University Hospital, Lund, Sweden. ${ }^{2}$ Cardiac MR group Lund, Dept. of Clinical Physiology, Lund University, Lund, Sweden. ${ }^{3}$ Department of Cardiology, Lund University Hospital, Lund, Sweden. ${ }^{4}$ Dept. of Medical Imaging and Physiology, Lund University Hospital, Lund, Sweden.

Published: 3 February 2015

\section{doi:10.1186/1532-429X-17-S1-Q85}

Cite this article as: Stephensen et al: Factors determining exercise capacity in patients with atrial septal defect: assessment of heart function with CMR during dobutamine stress. Journal of Cardiovascular Magnetic Resonance 2015 17(Suppl 1):Q85.
Submit your next manuscript to BioMed Central and take full advantage of:

- Convenient online submission

- Thorough peer review

- No space constraints or color figure charges

- Immediate publication on acceptance

- Inclusion in PubMed, CAS, Scopus and Google Scholar

- Research which is freely available for redistribution

Submit your manuscript at www.biomedcentral.com/submit 